15. Malaniuk, Ye. (1997). Do problemy etnopsykholohii malorosiistva [To the problem of ethnopsychology of Little Russians]. Narodna tvorchist ta etnohrafiia, 1, 41-52 [in Ukrainian].

16. Malaniuk, Ye. (1966). Malorosiistvo [Little Russianness]. Knyha sposterezhen. Proza. Toronto : «Homin Ukrainy» [in Ukrainian].

17. Moskalets, V.P. (1994). Psykholohichne obgruntuvannia ukrainskoi natsionalnoi shkoly [Psychological justification of the Ukrainian national school]. Lviv: Svit [in Ukrainian].

18. Riabchuk, M. (2000). Vid Malorosii do Ukrainy: paradoksy zapizniloho natsiietvorennia [From Little Russia to Ukraine: the paradoxes of the late-generation nationbuilding]. Retrieved from: http://www.exlibris.org.ual [in Ukrainian].

19. Sverstiuk, Ye. (1993). Bludni syny Ukrainy [Prodigal sons of Ukraine]. Kyiv: Znannia [in Ukrainian].

20. Severyniuk, V. \& Khoma, N. (2015). Syndrom malorosiistva. Novitnia politychna leksyka (neolohizmy, okazionalizmy ta inshi novotvory) [Syndrome of Little Russianness. Newest political vocabulary (neologisms, occasional and other new werpal forms)]. [I. Ya. Vdovychyn, O. M. Sorba, L. Ya. Uhryn ta in.]; za zah. red. N. M. Khomy. Lviv: Novyi svit - 2000 [in Ukrainian].

21. Chornyi, P. \& Liubarskyi, R. Malorosiistvo: khto komu Holokhvastov [Little Russianness: who is Golokhvastov to whom?]. Retrieved from: https://www.stepup.press/ kultura/item/ [in Ukrainian].

22. Shevchenko, T. (2003). Do Ya. H. Kukharenka. 31 sichnia 1843 r. [To Y.G. Kukharenko. January 31, 1843]. S.-Peterburh. Shevchenko T. H. Povne zibrannia tvoriv u 12-y tomakh. Kyiv: Naukova dumka, T. 6: Lysty. Darchi ta vlasnytski napysy. Dokumenty, skladeni T. Shevchenkom abo za yoho uchastiu [in Ukrainian].

Одержано 03.03.2019.

\section{УДК 911.3:33:001.82}

\section{Чернов Борис,}

кандидат педагогічних наук, професор, завідувач кафедри географії, екології і методики навчання olimp-deodraf@ukr.net http://orcid.org/0000-0001-8504-5248 Державний вищий навчальний заклад «Переяслав-Хмельницький державний педагогічний університет імені Григорія Сковороди», вул. Сухомлинського, 30, м. Переяслав-Хмельницький, Київська обл., Україна, 08401

\section{DOI https://doi.org/10.31470/2415-3567- 2019-45-114-123}

\section{Chernov Borys,}

Candidate of Pedagogy, Professor, Head of

Geography, Ecology and Methods of

Teaching Department

olimp-deodraf@ukr.net

http://orcid.org/0000-0001-8504-5248

Pereiaslav-Khmelnytskyi Hryhorii

Skovoroda State Pedagogical University, 30, Sukhomlynsky Str.,

Pereiaslav-Khmelnytskyi,

Kyiv region, Ukraine, 08401

\title{
THE METHODOLOGICAL BASIS OF ECONOMIC GEOGRAPHY
}

Today, global economic changes require a solution of many issues related not only to the improvement of new technologies in industry, agriculture, but also in area of solution of problems of internal and external migration of population. These issues up to 60-ies of XX 
century were integral parts of economic geography. Economic geography in this period made a considerable progress; it has been recognized not only in our country but also abroad. Evidence of this was the triumph of international scientific conferences and numerous publications. After a lengthy discussion, the economic geography as a separate independent science ceased to exist.

In economic geography has formed an uncertainty situation of its status: today, some geographers affirm that economic geography no longer executed function as an independent science and became addition to other sciences. After a long and emotional discussion «the fate» of economic geography had been determined - it had become part of other sciences, "ssocial geography" and "social and economic geography». However, new sciences can't be without economic geography. Therefore, there was a problem ascertain the current status of economic geography in the system of geographical sciences. In fact, it is self-sufficient science. For proving this statement, we determined the ways for further research.

Key words. Economic geography, social, socio-economic, public geography, relationships and influences, geography crisis, debate, loss of independence, new studies.

\section{ЕКОНОМІЧНА ГЕОГРАФІЯ: ІСТОРІОГРАФІЯ ÏÏ МЕТОДОЛОГІЧНОЇ СУТНOCТI}

До середини XX ст. складовою частиною економічної географії крім енергетики, промисловості, сільського господарства суттєвою частиною до ї̈ змісту входили із сочіальної сфери трунтовні питання розв'язання проблем внутрішньої $i$ зовнішньої міграції населення та його розселення, віковий склад, проблеми сім'ї. Проте, у цей період економічна географія серйозної кризи $і$ була піддана жорсткій критиці з вимогою ії включення складовою частиною до сочіальної географії, до сочіально-економічної або й заміну на суспільну географію. I ие не дивлячись на те, щзо економічна географія входить до названих наук основною частиною, тобто їх ядром. Значною мірою вплинули на зміну статусу економічної географії рішення ХХІІІ Міжнародного географічного конгресу (Москва, 1976) на значну увагу досліджень саме соиіального спрямування.

В економічній географії склалася ситуаџія невизначеності ї̈ статусу: на сьогоднішній день з тверджень окремих географів економічна географія перестала виконувати функцію самостійної науки і перетворилась на додаток інших наук. Після тривалої та емоційної дискусії доля економічної географії була вирішена - вона стала частиною інших наук: "сочіальної географії», «сочіальної і економічної» та "суспільної географії». I саме парадоксально, щзо нові науки не можуть обійтись без економічної географії. Тому й постала проблема з'ясування сучасного статусу економічної географії в системі географічних наук. Насправді вона є самодостатньою наукою. Для доведення цього твердження намічені шляхи подальших досліджень.

Ключові слова: економічна географія, соціальна, соціально-економічна, суспільна географія, взаємозв'язки і впливи, криза географії, дискусія, втрата самостійності, нові дослідження.

Verify the meaning of words, and you will save the mankind from half of their delusions.

(Rene Descartes)

Today, as a result of the accelerating processes of restructuring of the state and its economy there is a requirement for not only the fundamental changes in geographic science but also in the disproportion between natural and historical and social directions in geography. More active development of the social geography in foreign countries is explained by the market needs, profits, competitions, social inequality. But now all these have come to our state. A growing role of social science research has become more evident in providing nation-building, economic restructuring in the conditions of almost absolute privatization, commodity and market 
relations, the sudden enhancement of social economic direction, the incredibly quick growth of social inequality, the disastrous decline of agriculture, the aggravated political processes.

Under these conditions, «there was a need, on the one hand, to strengthen the theoretical, especially methodological and methodical potential of the national geographic science that would allow it as the geography of many developed countries to put and solve the most complex problems of environment, territorial aspects of social and economic development and the interrelation of the natural conditions, economy, culture, health and social well-being of a man. On the other hand, there is a complicated problem of active inclusion of geographic science in solving many practical problems of social revolution on the extremely difficult and rich for unpredictable events of the present stage of its development» [9, p. 8]. Certainly, there may be an immediate opinion that an important role has to be played by economic geography, but the priority is given to social geography. There is a problem of finding out a status of economic geography in contemporary rapidly changing world.

Analysis of the late researches and publications. The scientists study mainly problems of social geography but they don't leave behind attention and economic geography, in particular: M.D. Pistun «Theoretical Basics of Social Geography» (1996); O.H. Topchiev «Basics of Social Geography» (2001); O.I. Shablii «Basics of Social Geography» (2012) and others. O.I. Shablii developed his classification of social sciences, which united 61 sciences, economic geography he referred to «a block the main disciplines, beside with geography of population, social and political geography» [27, p. 20-21].

However, O.H. Topchiev ambiguously affirms that «soviet «economic geography» gradually has been transforming for the past ten years» from an independent science first in «economic and social» and later in «social and economic». Nowadays, this transformation comes to its logical conclusion, namely: holding courses from «social geography» in which economic geography is one of the components of social geography» [25, p. 179]. But, O.H. Topchiev, in another work on the geosphere, notes that «additional derivatives of geosphere are possible. For example, sociosphere can differentiate in economy sphere (social production processes), and in the sphere of spiritual life» [26, p. 79]. Thus, we can say that as a result of the complex and lengthy scientific way economic geography lost its independence.

The purpose of research is to determine the current status of economic geography, which in the opinion of some economic geographers lost its independence and has become addition to other social geographical sciences, although these sciences have not yet fully decided today or have insufficient theoretical and methodological grounds but economic geography differently is included in there structure.

The research objectives are to establish the reasons of changes the meaning of economic geography in the system of geographical sciences.

Statement of the main material. Philosophy, as the science of the general principles of being and knowledge, the essence and general natural laws, society and thought, forms the general system views on the world and place of a man in it. Philosophy, acting as general methodology of the objective knowledge world, enables possibility every science, in particular economic geography, to ground its own methodological basis. Today, the favourable conditions have developed for such grounds.

Firstly, the progressive development of philosophy with their inherent systemic vision of the world has led to the isolation of geographical landscapes, the essence grounds of geographical surface of the Earth, ways of existence which is the geographical form of the matter motion. Conversion from geological form of the matter motion in geographic allows really to study the history of appearing of geography that explains the theory of geography and is actively formed.

Secondly, the philosophical categories of general, special and individual enable geographers to study the object of geography - the geographical surface of the Earth, that for its complexity gives way except for philosophy, - at three levels: global or planetary (general physical geography), regional or state (regional geography) and local (regional ethnography). A 
dialectical method, as the methodological basis of knowledge of the natural and social reality, «in relation to scientific knowledge performs the integration and unifying function, overcoming apparent at first view the incompatible and the opposite of natural and scientific and social knowledge, identifying internal unity, universality of these different spheres human knowledge, explaining it as a reflection of the material unity of the world, which is in the process of continuous movement and development» [8, p. 7]. This allows the theory of geography «to plunge into the essence of the research objects, to remove the imaginary independence of separate phenomena, to lead them to an internal basis as a manifestation of the inner nature of the geographic relationship system» [20, p. 17].

Geography is the science about «the laws of space-time systems development, which are formed on the earth's surface (on a scale of general geographic and thematic maps) in the process of interaction between nature and society, the methods of regulation of these systems and their management.

«Space-time system - a landscape and landscaped areas, oceans and seas, river basins, lake hollow, biogeocoenoses, territorial and production systems (complexes), industrial hubs and industrial areas, economic areas, transport networks and systems, the city as a system and system of cities, areas of settlement, resort areas and etc. Every of these systems have be examined in interaction of nature and society, which are the essence of all geographic science, its unity and integrity» [23, p. 11].

Today, to understand the unity of geography and to find out individuality of objects study of physical and economic geography in this unity are extremely difficult, because the most geographers have not consensus of opinion. This refers particularly of economic geography: today, it is unknown what status it has? Has economic geography really stopped to perform its functions yet and became an insignificant addition to other sciences? And what is it the science at present: social, social and economic, social or still economic and geographic?

These questions ought to study and ascertain a place of science in the system of natural and social sciences. They are basic to the methodological justification. Without solving the main problem, it is not possible to solve partial ones, as the one «who takes to solve partial problems without solving the general, all the same will come across from these general problems» $[15, \mathrm{p}$. 368]. However, it is important not to give this problem «lost in a lot of other problems or a huge variety of contrary opinions, the most important here, to approach the question in terms of research, namely not forget the underlying historical connection, to look at this problem from viewpoint of the historical origin of the known phenomenon, which the main stages in its development, and that is actual for it today» [16, p. 67].

In the middle of the 60-s of the XX century the theory of economic geography was filled by M.M. Baranskyi' ideas, and his followers quietly resting on their laurels, affirmed that «economic geography plays more an importance role in society. This is well illustrated by the International Geographical Congress for the last ten years in which economic geography was and remains widely acknowledged «Queen» [28, p. 5].

However, the situation changed dramatically in the 70-th years. The powerful attack began on economic geography, its existence as an independent science was questioned, since the economic geographers did not understand the differentiation of geography science and thus critically were expressing in its address, namely:

1) economic geography is «in crisis situation» because «ill-founded of its methodology», ill-defined of the scientific research subject, «insufficiently shown up of an inherent mechanism of economic and geographic processes and phenomena», and its coordinating and integrating role in solving interdisciplinary problems of rational use, the environment protection and its preservation «gradually goes to economists, and not the economic geographers» [1, p. 14];

2) economic geography lacks the «highest level of its content, similarly to the general natural geography» $[20$, p. $144 ; 7$, p. $305 ; 22$, p. 24];

3 ) the state of economic geography «is not up to the level as a number of related science and practice needs» [20, p. 148] and it falls behind of life [17]; 
4) «a spatial (territorial) approach is caused by «sprawling» economic geography because of ill-defined the research subject» [5, p. 288]. As to the crisis of economic geography the foreign geographers expressed too $[29 ; 30]$.

What was happened with such, at first sight, prosperous science as economic geography? The reason was in ideologization.

Ideologization of all geography was manifested in different forms. «The fight with various «ideological» movements was affected adversely on development of geography in the 30-s-50-s years of the XX century. The fundamental ideas of geography were declared by scholasticism, a man always was opposed to nature. Anthropogeography and demography were defeated and political geography was depressed» $[9$, p. 63].

In the 40-s years of the XX century «Leningrad affair» was falsified, «the defeat of Leningrad University was organized by A.A. Voznesenskyi, the fight with «rootless cosmopolitan» was started. Ya.S. Edelshtein, outstanding geographer, died in the prison, V.M. Shtein, Dean of the Geography Faculty of LSU, was repressed» [6, p. 128].

At this time orientation of all geography was unilaterally pragmatic, especially its social sphere. «The dogmatism and blind following the leaders' instructions were prospered in geography science. Narrow regional studies were encouraged, they pursued specific objectives, without going out the general problems of science, without searching and analysis of the objective laws of development of the natural environment and society» [10, p. 7].

In the 60-s years of the XX century began «thaw», but it quickly passed, creating a period of «stagnation» in which all the negative trends extended in geographical science. These are: «antistate and antisocial personnel policy, creation of privileged «nomenclature» caste in science, politics ban on the profession, in other words in science began not allow for talent, and the questionnaire. «Dissidents» had not been shot yet, but they were pursued and sent in the «mental hospitals» and denaturalized» [6, p. 129].

As noted V.M. Kotliakov, the result of aforesaid «was the de-intellectualization of science; in the USSR geography began to dramatically lag behind the world level in many positions. This is especially evident in areas of social geography. The most of studies were conducted «in the interest» of BAM, transfer of the river flow and etc. These studies led to the loss of culture scientific work that facilitated to the separation Geography from the fundamental sciences... Theoretical analysis largely carried scholastic character, and mostly was grounded in the foreign works that had been recognized (D. Harvey, P. Haggett, R. Johnston and others)» [10, p. 7]. Moreover, the distortion of the scientific normal form activity «opened the way for causal scientists, but with good questionnaire and well-connected with the local elite. If take into consideration that corruption, bribery, dressing, protectionism, sectionalism were penetrated in science, that can imagine how it was polluted by careerists, ignorant people and hoodwinkers. However, these figures had got all the advantages of geography at international scientific forums» [6 p. 129]. Here, it should be remembered the foreign geographers' dictums. For example, the outstanding French geographer about the state of the world geography spoke so: «Crisis? - Certainly, it is! The scientific discipline, which would not know crisis, would have fallen into slumber, began to die... So if you want - a crisis! The crisis has its positive and negative phenomena» [14, p. 6-7].

If take into consideration that in this period and in the world scientific geographical literature denoted that the economic geography was being in deep long crisis so as all geographical science $[6$, p. $97 ; 18$, p. 17], we can only imagine the confused state of the economic geographers who suddenly found themselves on the complicated way. Nothing remained, as everyone together to critic economic geography, namely: «methodological basis» is absent in it, «object is not clearly defined», «higher level of its content is not sufficed», «it does not correspond to the needs of the practice», it lags behind life and etc.

It is interesting that all were satisfied the scientific development. For example, 100 collections on «Problems of geography» were issued by the Moscow Affiliate of the Geographical Society of the USSR for 30 years (1946-1976), among of them 16 related to 
economic geography, 10 - population geography and geographical areas, 2 - geography of services and geography of tourism [24, p. 227]. Economic geographers were untroubled, and suddenly they had found out that reason for all that was economic geography!

An analysis of publications on economic geography for all these years was shown that in economic geography were all grounded by these same authors. Then arise the question: Has economic geography as science exhausted itself? But is it so? It appears that some truth in this is, because «gradually the modern economic geography was being accumulated new facts which did not fit into the framework of the existing concept, formed critical positions in relation to the existing theoretical principles, and new socio-economic and geo-environmental situations demanded new solutions» [19, p. 155]. But there were no new solutions.

After a short time, «new solutions» came out of wastes of history and it was called sociologization of science.

In principle, this change of the research direction should be considered as a natural phenomenon, since it reflects the new social order of society, which coincided with the beginning sociologization of social practice.

Sociologization is a general direction of all science and social practice, closely connection with humanization, which manifests itself in increasing attention to the social aspects of development. In the 30-s years of the XX century, M. Baranskyi wrote about the need sociologization of geography. In this period anthropogeography and demography development was interrupted in the former USSR, and all «unnatural» geography was practically led to study the economic sphere of society. Then sociologization was «choked», it was explained the industrial development of economy and scientific dogmas and bans, that existed after the defeat of anthropogeography and demographics. Thus «production definition the essence of economic geography, where the population was seen as a labor resource and the some masses which consume industrial products and food» was formed for many years and attached in geographical science and consciousness scientists [17, p. 23].

And here in the late 60-s - early 70-s of the XX century, at first, sociologization of science suffered «doubtful revival», and then was «more rapid» development. Ya.S. Nymmyk, exploring the basic theoretical problems of sociologization economic geography and the formation of social and economic geography, cleared up that in 1968 Yu.H. Saushkin («the socio-economic territorial system» and «socio-economic spatial system») and A.M. Kolotiievskyi with the Tartu's scientists («the socio-economic territorial complex» and «socio-economic region») introduced the foundations of conceptual fund [19, p. 155].

Later, in the 70-s years of the XX century, such the outstanding economic geographers as N.T. Ahafonov, E.B. Alaiev, S.B. Lavrov, V.V. Pokshyshevskyi and others affirmed that economic geography should be called socio-economic or even wider - the social sciences [2; 13; 21]. S.B. Lavrov and N.T. Ahafonov, analyzing the actual problems of economic geography at the XXIII International Geographical Congress (IGC, 1976), noted that should distinguish the social and economic geography as an independent science. After S.B. Lavrov and H.V. Sdasiuk, describing the development of modern economic and social geography, noted that «the leading role of the modern world geography belongs to social and economic problems» [14, p. 6; marked bold by the author]. The authors affirmed that «the underlying sociologization processes pervade all economic geography, make it economic and social, and they are two inextricably linked one subsystem of geographical sciences. No non-social economic phenomena. No «non-social» economic development» [14, p. 10]. Therefore, vast majority of the economic geographers were surprised results of the XXIII International Geographical Congress, because in some geographers' domestic and foreign reports, «with all the differences of methodologies dominant, was the idea of «sociologization» economic geography and the formation of social and economic geography» $[12$, p. 4]. And since the beginning of the 80-s years of the XX century in scientific articles and works confidently noted that the in the 70-s years «economic geography everywhere is social and economic $»[14$, p. 11; underlined and marked bold by B. Chernov]. All this cleared up quite evident in the scientific views of E.B. Alaiev. 
Thus, E.B Alaiev after the Congress first carefully admitted that the term «economic geography» in relation to the discipline, as it is treated in science, narrow compared with the contents of the scientific discipline; in any case, the term «socio-economic geography» might be more perfect» [2, 129]. And in 1980, scientist categorically (expression of Nymmyk S.Ya.) affirmed: «Now is the time to emphasize that domestic economic geography transformed in social and economic geography» $[3,89$; underlined by B. Chernov]. However, any justification was not said by the author.

But then adherents appeared which extremely emotional supported «birth» and existence of socio-economic geography. N.K. Mukitanov, Z.E. Dzenis, Yu.V. Porosionkov, M.D. Sharyhin, S.A. Kovaliov and others wrote about the need of socio-economic geography development. Analyzing these publications, S.Ya. Nymmyk noted that, for example, N.K. Mukitanov confined only a general statement of the need of social geography as the only true way of sociologization of geographical knowledge. Z.E. Dzenis correctly spoke of the need to ground the research objects of social and socio-economic geography, but he did not substantiate of them. The actual problems of content and methodological problems of socioeconomic geography were not considered by other researchers.

It remains unclear actual methodological question: how geographic science correlates with economic geography, social, socio-economic and political geography. In these methodological constructions hidden internal inconsistency that defines the relationship between the sciences. The answers to these and other questions require further painstaking study.

\section{ДЖЕРЕЛА ТА ЛІТЕРАТУРА}

1. Агранат Г.А. География и экономика: связи и зависимости (к поискам путей развития экономической географии) // Известия АН СССР. Сер. Геогр. 1977. № 6. С. 1326.

2. Алаев Э.Б. Экономико-географическая терминология. Москва: Мысль, 1977. 199с.

3. Алаев Э.Б. Социально-экономическая география: Актуальные вопросы развития науки // Известия АН СССР. Сер. Геогр. 1980. № 4. С. 89-94.

4. Анненков В.В., Герасимов И.П., Минц А.А. Этапы развития современной географии // Известия АН СССР. Сер. Геогр. 1972. № 3. С.90-100.

5. Дружинин А.Г. География культуры: некоторые аспекты формирования нового научного направления // Известия ВГО. 1989. Т. 121. Вып. 4. С.307-312.

6. Исаченко А.Г. География на перепутье: уроки прошлого и пути перестройки // Известия ВГО. 1990. № 2. С. 127-137.

7. Исаченко А.Г. О единстве географи // Известия ВГО. 1971. Т. 103. Вып. 4. С. 289310.

8. Исторический материализм как методология познания и преобразования общественной жизни / Под ред. В. В. Денисова. Москва: Наука, 1987. 284с.

9. Котляков В.М. Географические аспекты нового мышления // Коммунист. 1990. № 11. C. 61-70.

10. Котляков В.М. Географическая наука на пороге 90-х годов // Известия АН СССР. Сер. Геогр. 1990. № 4. С. 5-16.

11. Котляков В.М., Анненков В.В. XXVI Международный географический конгресс // Известия АН СССР. Сер. Геогр. 1989. № 1. С. 7-19.

12. Лавров С.Б.,Агафонов Н.Т. Принципиальные вопросы экономической географии на ХХШ Международном географическом конгрессе // Известия ВГО., 1977. Вып. 1. С. 47.

13. Лавров С.Б., Агафонов Н.Т. Теоретические споры и некоторые научнопрактические задачи экономической географи // Известия ВГО, 1974. Вып. 2. С.148.

14. Лавров С.Б., Сдасюк Г.В. Советская социально-экономическая география: некоторые аспекты международного значения // Региональный экономикогеографический анализ и прогнозирование. Фрунзе, 1980. С.11-13. 
15. Ленин В.И. Отношение к буржуазным партиям. ПСС. Т. 15. С. 7-68.

16. Ленин В.И. О государстве. ПСС. Т. 39. С. 368-369.

17. Максаковский В.П. Географическая культура: Учебное пособие для студентов вузов. Москва: Гуманит. изд. центр ВЛАДОС, 1998. 416 с.

18. Машбиц Я.Г. Тенденции развития географической мысли // Известия АН СССР. Сер. Геогр. 1990. № 4. С. 17-27.

19. Мересте У.И., Ниммик С.Я. Современная география: вопросы теории. Москва: Мысль, 1984. 296 с.

20. Мукитанов Н.К. От Страбона до наших дней. Москва: Мысль, 1985. 234 с.

21. Покшишевский В.В О самом главном в экономической географии // Вопросы географии. Москва: Мысль, 1974. № 95. С. 25-42.

22. Преображенский В.С. Феномен географии (раздумья географа) // Известия АН СССР. Сер. Геогр. 1979. № 4. С. 20-27.

23. Саушкин Ю.Г. Географическая наука в прошлом, настоящем, будущем: Пос. для учитителей. Москва: Просвещение, 1980. 269 с.

24. Перспективы географии // Сто сборников «Вопросы географии». Москва: Мысль, 1976. Сб. 100. $254 \mathrm{c}$

25. Топчієв О.Г. Основи суспільної географії: Навч. посібник. Одеса: Астропринт, $2001.560 \mathrm{c}$.

26. Топчієв О.Г. Концептуально-поняттєвий апарат і предметна область географії // Теоретичні та методологічні проблеми суспільної географії: Зб. наук. праць на пошану Заслуженого професора Львівського національного університету імені Івана Франка Олега Шаблія. Львів: Видавничий центр ЛНУ ім. Івана Франка, 2006. С. 77-84.

27. Шаблій О.І. Основи суспільної географії: підручник для студ. Вищих навч. закладів. 2-ге вид. Львів: ЛНУ імені Івана Франка, 2012. 296 с.

28. Экономическая география в СССР: история и современное развитие / Под ред. Н.Н. Баранского и др. Москва: Просвещение, 1965. 653 с.

29. Gillmor Desmond A. Economic geography: its scope, development and methodology / Gillmor Desmond A. «Geogr. Viewpoint», 1968, 1. № 5. 251-260.

30. Mazúr T. Geography of today and its perspective. «Geogr. časop.», 1968, 20. № 3. 201-211.

\section{REFERENCES}

1. Agranat, G.A. (1997). Geografija i jekonomika: svjazi i zavisimosti (k poiskam putej razvitija jekonomicheskoj geografii) [Geography and Economy: Communication and Dependence (Search of the Ways of Economic Development Geography)]. Proceedings of the Academy of Sciences of the USSR. Series: Geography, 6, 13-26 [in Russian].

2. Alaev, Je.B. (1977). Jekonomiko-geograficheskaja terminologija [Economic and Geographic Terminology]. Moscow: Mysl [in Russian].

3. Alaev, Je.B. (1980). Social'no-jekonomicheskaja geografija: Aktual'nye voprosy razvitija nauki [Socio-Economic Geography: Actual Problems of Development of Science]. Proceedings of the Academy of Sciences of the USSR. Series: Geography, 4, $89-94$ [in Russian].

4. Annenkov, V.V., Gerasimov, I.P., Minc, A.A. (1972). Jetapy razvitija sovremennoj geografii [Stages of Modern Development Geography]. Proceedings of the Academy of Sciences of the USSR. Series: Geography, 3, 90-100 [in Russian].

5. Druzhinin, A.G. (1989). Geografija kul'tury: nekotorye aspekty formirovanija novogo nauchnogo napravlenija [Geography of Culture: Some Aspects of the Formative New Scientific Direction]. Proceedings of the VGO, 121 (4), 307-312 [in Russian].

6. Isachenko, A.G. (1990). Geografija na pereput'e: uroki proshlogo i puti perestrojki [Geography at the Crossroads: Lessons of the Past and Ways of Rebuild]. Proceedings of the Academy of Sciences of the USSR. Series: Geography, 2, 127-137 [in Russian].

7. Isachenko, A.G. (1971). O yedinstve geografii [About Unity of Geography]. 
Proceedings of the VGO, 103 (4), 289-310 [in Russian].

8. Denisov, V. ed. (1987). Istoricheskij materializm kak metodologija poznanija $i$ preobrazovanija obshhestvennoj zhizni [The Historically Materialism as Methodology Cognition and Transformation Social Life]. Moscow: Nauka [in Russian].

9. Kotljakov, V.M. (1990). Geograficheskie aspekty novogo myshlenija [Geographic Aspects of the New Thinking]. Communist, 11, 61-70 [in Russian].

10. Kotljakov, V.M. (1990). Geograficheskaja nauka na poroge 90-h godov [Geographic Science at the Threshold of 90-s]. Proceedings of the Academy of Sciences of the USSR. Series: Geography, 4, 5-16 [in Russian].

11. Kotljakov, V.M., Annenkov, V.V. (1989). XXVI Mezhdunarodnyj geograficheskij kongress [XXVI International Congress of Geography]. Proceedings of the Academy of Sciences of the USSR. Series: Geography, 1, 7-19 [in Russian].

12. Lavrov, S.B. \& Agafonov, N.T. (1977). Principial'nye voprosy jekonomicheskoj geografii na XXIII Mezhdunarodnom geograficheskom kongresse [Actaul Problems on Economic Geography at the XXIII International Congress of Geography]. Proceedings of the $V G O, 1,4-7$ [in Russian].

13. Lavrov, S.B. \& Agafonov, N.T. (1974). Teoreticheskie spory i nekotorye nauchnoprakticheskie zadachi jekonomicheskoj geografi [Theoretical Arguments and Some Scientific and Practical Problems of Economic Geography]. Proceedings of the VGO, 2, 148 [in Russian].

14. Lavrov, S.B. \& Sdasjuk, G.V. (1980). Sovetskaja social'no-jekonomicheskaja geografija: nekotorye aspekty mezhdunarodnogo znachenija [Soviet Socio-Economic Geography: Some Aspects of International Importance]. Regional Economic-Geographical Analysis and Forecasting, Frunze, 11-13 [in Russian].

15. Lenin, V.I. Otnoshenie k burzhuaznym partijam [Attitude to Bourgeois Parties]. PSS, 15, 7-68 [in Russian].

16. Lenin, V.I. O gosudarstve [About the State]. PSS, 39, 368-369 [in Russian].

17. Maksakovskij, V.P. (1998). Geograficheskaja kul'tura: Uchebnoe posobie dlja studentov vuzov [Geographic Culture: Textbook for students]. Moscow: Humanitarian Pub. Center VLADOS [in Russian].

18. Mashbic, Ja.G. (1990). Tendencii razvitija geograficheskoj mysli [Trends in the Development of Geographical Thought]. Proceedings of the Academy of Sciences of the USSR. Series: Geography, 4, 17-27 [in Russian].

19. Mereste, U.I. \& Nimmik, S. Ja. (1984). Sovremennaja geografija: voprosy teorii [Modern Geography: Theoretical Problems]. Moscow: Mysl [in Russian].

20. Mukitanov, N.K. (1985). Ot Strabona do nashih dnej [From Strabo to the Today]. Moscow: Mysl [in Russian].

21. Pokshishevskij, V.V. (1974). O samom glavnom v jekonomicheskoj geografi [On the Most Important in Economic Geography]. Problems of Geography, 95, 25-42 [in Russian].

22. Preobrazhenskij, V.S. (1979). Fenomen geografii (razdum'ja geografa) [Geographical Phenomenon (Thoughts of Geographer)]. Proceedings of the Academy of Sciences of the USSR. Series: Geography, 4, 20-27 [in Russian].

23. Saushkin, Ju.G. (1980). Geograficheskaja nauka v proshlom, nastojashhem, budushhem: Posobije dlja uchititelej [Geographical Sciences in the Past, Present, Future: Textbook for Teacher]. Moscow: Prosveshcheniie [in Russian].

24. (1976). Perspektivy geografii [Prospects of Geography]. One Hundred Collections «Problems of Geography». Moscow: Mysl, 100, 254 [in Russian].

25. Topchijev, O.H. (2001). Osnovy suspilnoji heohrafiji: Navch. Posibnyk [Basis of Social Geography: Manual]. Odesa: Astroprynt [in Ukrainian].

26. Topchijev, O.H. (2006). Konceptualno-ponjattjevyjj aparat i predmetna oblast heohrafiji [Conceptual Apparatus and Subject Area in Geography]. Theoretical and Methodological Problems of Social Geography: Coll. Scien. Works in Honour of Honoured Professor of Lviv Ivan Franko National University Oleh Shablii. Lviv: Pub. Center LNU named 
by Ivan Franko, 77-84 [in Ukrainian].

27. Shablij, O.I. (2012). Osnovy suspilnoji heohrafiji: pidruchnyk dlja studentiv vyshchykh navchalnykh zakladiv [Basis of Social Geography: Textbook for Students of Higher Education Institutions]. Lviv: LNU named by Ivan Franko [in Ukrainian].

28. Barans'kij, N.N. ed. (1965). Jekonomicheskaja geografija $v$ SSSR: istorija $i$ sovremennoe razvitie [Economic Geography in the USSR: History and Modern Development]. Moscow: Prosveshcheniie [in Russian].

29. Gillmor Desmond, A. (1968). Economic Geography: its Scope, Development and Methodology. Geogr. Viewpoint, 1 (5), 251-260.

30. Mazúr, T. (1968). Geography of Today and its Perspective. Geogr. časop., 20 (3), 201211.

Одержано 02.02.2019.

УДК 001:631.4(091) (477)

\section{Коблош Віталій,}

здобувач Національної наукової

сільськогосподарської бібліотеки НААН

dnsgb_uaan@ukr.net

https://orcid.org/0000-0001-8471-944X

Researcher ID: E-3704-2019

Національна

наукова

Сільськогосподарська бібліотека НААН

вул. Героїв Оборони, 10, м. Київ, Україна, 03127
DOI https://doi.org/10.31470/2415-35672019-45-123-130

Koblosh Vitaliy, post-graduate student of the National Scientific Agricultural Library of the NAS Ukraine dnsgb_uaan@ukr.net

https://orcid.org/0000-0001-8471-944X

Researcher ID: E-3704-2019

National Scientific Agricultural Library of the

NASUkraine

10, Heroes of Defense St. Kyiv, Ukraine, 03127

\section{МЕТОДОЛОГІЧНІ ЗАСАДИ КОМПЛЕКСНОГО АНАЛІЗУ ГРУНТОВО- КАРТОГРАФІЧНИХ МАТЕРІАЛІВ: 3 НАУКОВОЇ СПАДЩИНИ ПРОФЕСОРА Н.Б. ВЕРНАНДЕР}

У статті висвітлено один із важливих напрямів розвитку трунтознавчої науки в Україні впродовж першої половини XX сm., зокрема розробки основних принципів $i$ методів комплексного аналізу великомасштабних грунтово-картографічних матеріалів для складання районних, обласних та республіканської карт трунтів $i$ сільськогосподарської типологї землі. Із застосуванням принципів наукової об'єктивності, історичної достовірності, а також власне історичних методів (проблемно-хронологічного, біографічного, описового та ін.) з 'ясовано, щуо значний внесок для опраџювання методології обліку й аналізу земельних ресурсів України належить доктору сільськогосподарських наук, професору Вернандер Наталії Борисівні. Розкриття iї наукового доробку для розвитку вітчизняної грунтознавчої науки і стало метою даної публікації.

Встановлено, що впродовж 1930-1950 рр. професор Н.Б. Вернандер очолювала експедииійні роботи з обстеження трунтів різних областей України. На основі отриманих результатів досліджень створювали трунтові карти з текстами описів, але тривалий час трунтознавцям не вдавалося здійснити вичерпний облік, а відповідно й 